\title{
Synecology of Cutandia maritima (L.) Barbey, a rare psammophytic species along the Montenegrin Coast (East Adriatic Coast)
}

\author{
Danijela Stešević, ${ }^{*}$, Nada Bubanja², Danka Caković ${ }^{1}$, Nejc Jogan ${ }^{3}$, \\ Milica Luković ${ }^{4} \&$ Urban Šilc ${ }^{5,6}$
}

\begin{abstract}
Key words: Cutandia maritima, Velika plaža in Ulcinj, sand dunes, vegetation.
\end{abstract}

Ključne besede: Cutandia maritima, Velika plaža pri Ulcinju, peščene sipine, vegetacija.
Received: 2. 12. 2015

Revision received: 31. 1. 2017

Accepted: 2. 2. 2017

\begin{abstract}
Cutandia maritima is a circum-Mediterranean species that inhabits sandy dunes along the coast line. It is fairly frequent on the western Adriatic coast but fairly rare and possibly even non-native in the east. In Croatia, it was discovered in 1990 in Crnika Bay on the island of Rab, which was considered until 2005 to be the only site on the eastern Adriatic coast from the Gulf of Trieste in the north to Corfu in the south. In 2009, the species was briefly reported for Velika plaža (Long Beach) in Ulcinj (Montenegro) but without details about the habitat type and synecology. The aim of this paper is thus to provide a deeper insight into the ecology and synecology of $C$. maritima in the eastern Adriatic part of the distribution area. On Velika plaža in Ulcinj, the species was found along the whole sea-inland gradient of sand dunes, in various types of vegetation: [1210] - annual vegetation of drift lines, [2110] - embryonic shifting dunes, [2120] - shifting dunes with Ammophila arenaria (white dunes), [2220] - dunes with Euphorbia terracina, $\left[2130^{*}\right]$ - fixed coastal dunes with herbaceous vegetation (grey dunes), and also [2190] - humid dune slacks.
\end{abstract}

\begin{abstract}
Izvleček
Cutandia maritima je vrsta, ki uspeva na peščenih sipinah ob morskih obalah ob celotnem Mediteranu. Ob zahodnih obalah je precej pogosta, medtem ko je na vzhodu redka ali celo tujerodna. Na Hrvaškem so jo odkrili leta $1990 \mathrm{v}$ zalivu Crnika na otoku Rabu in to je bilo do leta 2005 edino nahajališče na vzhodni Jadranski obali med Tržaškim zalivom na severu in otokom Krfom na jugu. O najdbi vrste na Veliki plaži pri Ulcinju so na kratko poročali leta 2009, a brez podrobnosti o njenem rastišču in sinekologiji. $\mathrm{V}$ članku podajamo natančnejši vpogled v ekologijo in sinekologijo vrste $C$. maritima ob vzhodni Jadranski obali. $\mathrm{Na}$ Veliki plaži vrsta uspeva na peščenih sipinah na celotnem gradientu od morja $\mathrm{v}$ notranjost in $\mathrm{v}$ različnih vegetacijskih tipih: [1210] - Združbe enoletnic na obalnem drobirju, [2110] - Embrionalne premične sipine, [2120] - Premične sipine vzdolž obrežij z vrsto Ammophila arenaria (bele dine), [2220] - Sipine z vrsto Euphorbia terracina, [2130*] - Utrjene obalne sipine z zeliščno vegetacijo (sive dine), in [2190] - Vlažne uleknine na sipinah.
\end{abstract}

\footnotetext{
1 Faculty of Natural Sciences and Mathematics, Biology Department, Džordža Vašingtona bb, 81000 Podgorica, Montenegro *Corresponding author: danijela.stesevic@ac.me

2 Natural History Museum of Montenegro, Trg vojvode Bećir-bega Osmanagića 16, 81000 Podgorica, Montenegro

3 Department of Biology, Biotechnical Faculty, University of Ljubljana, Večna pot 111, SI-1000 Ljubljana, Slovenia

4 Faculty of Hotel Management and Tourism Vrnjačka Banja, University of Kragujevac, Vojvođanska 5A, 36210 Vrnjačka Banja, Serbia

5 ZRC SAZU, Institute of Biology, Novi trg 2, SI-1000 Ljubljana, Slovenia

6 BC Naklo, Strahinj 99, Naklo, Slovenia
} 


\section{Introduction}

Although Cutandia maritima (L.) Barbey is considered to be a common species on sandy dunes along the Mediterranean coast (van der Maarel \& van der MaarelVersluys 1996), its record in Montenegro (Velika plaža in Ulcinj) dates from 2005 (N. Jogan, unpublished); it was published in 2009 (Glasnović et al. 2009). It appears frequently on the western Adriatic coast (reported for all countries east of Italy (Pignatti 1982), while along the eastern coast it is fairly rare (Trinajstić 1994) and may even have been recently introduced (Horvat 1939). It is considered to be a focal species of 2230 EU habitat Malcolmietalia dune grasslands (Stanisci et al. 2014) and occurs in various plant communities of the Ammophiletea, Cisto-Micromerietea and Helminthemetea classes (Goday \& Martinez 1958, Bolos 1996, Costa et al. 2000, Sýkora et al. 2003, Zimmitti et al. 2015 etc.). It is a characteristic species of sabulicolous therophytic plant communities, which Rivas-Martínez et al. (2002) described as the Cutandietalia maritimae order within the class Tuberarietaria guttatae (syn. Helianthemetea guttati). This order comprises ephemeral vegetation growing on coastal sands and dunes with salt spray, as a therophytic vegetation type among the perennial vegetation of Ammophiletea, and it is distributed over the whole Mediterranean (Díez-Garretas et al. 2003). C. maritima is recorded in ca. 30 ephemeral plant communities that inhabit coastal sands and sand dunes with salt spray, among perennial vegetation of $\mathrm{Am}$ mophiletea, Crucianelletea and sometimes also Quercetea ilicis (Díez-Garretas et al. 2003, Minissale \& Sciandrello 2015). It appears as a dominant species in 7 associations and sub-associations: Vulpielo tenuis-Cutandietum maritimae (Rivas-Martinez et al. 2002), Cutandio maritimaeParapholidetum marginatae (Bartolo et al. 1988), Sileno sericeae-Cutandietum maritimae (Géhu \& Biondi 1994), Sileno nicaensis-Cutandietum maritimae (Géhu \& Biondi 1994), Matthiolo tricuspidatae-Cutandietum maritimae (Géhu et al. 1987), Sileno succulentae-Cutandietum maritimae (Géhu \& Géhu-Franck 1986), Sileno ononidetum variegatae subass. Cutandietosum maritimae (Minissale \& Sciandrello 2015), mainly distributed in the western part of the Mediterranean.

Sabulicolous therophytic plant communities in the Mediterranean are also classified into the order Malcolmietalia. Both orders are mainly dominated by annual plants with a short lifecycle growing on non-nitrified deep sandy soils. The optimum of Malcolmietalia communities is siliceous sands or paleodunes in the western Mediterranean, where they are a subseral stage of Quercus suber forests or Juniperus navicularis and J. broussonetii open woodlands. They are assumed to be indicators of conti- nentality, whereas those of Cutandietalia are indicators of less expressed climatic conditions. Good correspondence is also shown along the altitudinal gradient and distance from the sea (Minissale \& Sciandrello 2015). In the eastern Mediterranean, C. maritima is characteristic of the central fore-dune ridge (Doing 1985).

In other parts of the Mediterranean, the species $C$. maritima occurs rarely in Cakiletea plant communities (frequency class lower than II), while it is more frequent (frequency class IV) in plant communities of Ammophiletea and has the status of differential species (e.g. Limonio graeci-Triplachnetum nitentis centaureetosum aegialophilae Mayer 1995) (Brullo \& Furnari 1970, Brullo et al. 1974, Perdigó \& Papió 1985, Sykora et al. 2003 etc.). It is also a companion species of chamaephytic and hemicryptophytic Crucianelletalia maritimae plant communities (e.g. Centaureo-Oninidetum ramosissimae) usually confined to dunes further inland with little movement (Zimmitti et al. 2015), as well as Malcolmietalia Rivas Goday 1958 communities (e.g. Violo henriquesii-Silenetim littoreae Izco \& Guitian 1988; Costa et al. 2000).

In previous studies of sand dune vegetation of Velika plaža in Ulcinj, only communities of Cakiletea maritimae and Ammophiletea were mentioned (Trinajstić 1989, Mijović 1994, Mijović et al. 2006, 2012, Šilc et al. 2015), while sabulicolous therophytic communities were not taken into account. The aim of this paper is to provide a deeper insight into the ecology and synecology of the species C. maritima in Montenegro and to initiate more detailed investigation of annual sand dune vegetation on Velika plaža.

\section{Materials and methods}

\section{Study area}

Velika plaža in Ulcinj (Velika plaža, Montenegro) is considered to be the longest beach on the eastern Adriatic coast (ca. $12 \mathrm{~km})$, with still well preserved sand dune vegetation. Since 1968, the beach has been recognized as a monument of nature (Official Gazette of the Social Republic of Montenegro, SRCG 30/68). According to the Spatial Plan of Special Purpose for the Coastal Zone, one spatial unit on the east side of Velika plaža is recognized as a new protected nature reserve, with forests, marshes and meadows. The area is protected from trampling or grazing with a wooden fence (JPMD 2015, Šilc et al. 2017). However, the rest of the beach, which represents more than $75 \%$ of natural coast and $97 \%$ of whole sand dune system, is heavily impacted by tourism, illegal dumping, sand exploitation and urbanization (Petrović 
\& Karaman 2009). Eleven NATURA 2000 habitats are reported for the beach and its hinterland (Petrović et al. 2012) and the site is included in the list of IPA areas (Petrović \& Karaman 2009).

\section{Data collection and analysis}

During 2015, the floristic composition and zonation of plant communities on Velika plaža in Ulcinj were studied. Twenty transects were set perpendicular to the coast, at a distance from each other of cca. $500 \mathrm{~m}$. Contiguous quadrats $(2 \times 2 \mathrm{~m})$ were laid out in the form of a belt transect (Kent 2012), starting from the area with the first colonizing plants towards the end of the sand dune system up to forest vegetation. In each quadrat, the cover of plant species was visually estimated by the Braun-Blanquet (1964) scale. Plants were determined following Pignatti (1982) and Tutin et al. (1964-80). All gathered relevés were entered into the TURBOVEG (Hennekens \& Schaminée 2001) database.

Multivariate analysis (Ward method and Euclidean distance) of the plots was performed in PC-ORD (McCune\& Grace 2002) to recognize plant communities on sand dunes. Clusters were identified by their diagnostic species, using the JUICE program (Tichý 2002). Three species with the highest fidelity were selected for each cluster. Relevés with $C$. maritima were selected, presented in a single table (Table 1) and classified into different clusters.

Detrended Correspondence Analysis (DCA) ordination was used to visualize the floristic similarity of plots. Species cover values (mean percentage values) were square-root transformed. DCA was done in CANOCO 5 program (ter Braak \& Šmilauer 2012).

The nomenclature of taxa is according to Tutin et al. (1964-80).

\section{Results}

Within the part of the study concerning the floristic composition and zonation of plant communities on Velika plaža in Ulcinj, 20 transects were set perpendicularly from the sea towards inland and 876 relèves were done. In further analysis, they were classified into 9 clusters corresponding to 9 plant communities (Cakilo-Xanthietum italici, Cynodon dactylon comm., Euphorbio paraliaeAgropyretum junceiformis, Medicagini marinae-Ammophiletum australis, Onobrychis caput-galli comm., Cladietum marisci, Eriantho-Schoenetum nigricantis, Juncetum maritimo-acuti, Holoschoenetum romani) or to 7 NATURA 2000 habitats (Figure 1). The species C. maritima was recorded in 4 transects and 33 quadrats (Table 1), distributed in a bandwidth from ca. $80 \mathrm{~m}$ from the sea to $150 \mathrm{~m}$ inland. Its cover value is lower $(\mathrm{r},+$ and 1$)$ in mobile parts of dunes and higher (1) in more stabilized parts of dunes covered with Onobrychis caput-galli comm. and Holoschoenetum romani (Figure 1).

During the floristic survey along Velika plaža in Ulcinj, C. martima was fairly frequently recorded along almost the whole gradient of sand dune vegetation, although never in great abundance. It starts to appear either in the zone of annual vegetation of drift lines (EU habitat 1210) or in the transitional zone among annual vegetation of drift line sand embryonic shifting dunes (EU habitat 2110), which is characterised by intensive impact of wind and salt spray and fairly low vegetation cover. It also penetrates deeper into the vegetation of shifting dunes with Ammophila arenaria (white dunes, EU habitat 2120), dunes with Euphorbia terracina (EU habitat 2220), fixed coastal dunes with herbaceous vegetation (grey dunes, EU habitat $2130^{*}$ ) and humid dune slacks (EU habitat 2190).

\section{Discussion}

The first record of C. maritima in Montenegro dates back to 2005 (N. Jogan unpublished) and it was later published in Glasović et al. (2009) since it had not been mentioned in previous (Trinajstić 1989, Mijović 1994, Mijović et al. 2006) and recent (Mijović et al. 2012) vegetation studies of the dune vegetation of Velika plaža. In neighbouring Croatia, the species was also discovered fairly late, in 1990 in Crnika Bay on the island of Rab, so up to 2005 it was considered to be the only site on the eastern Adriatic coast from the Gulf of Trieste in the north to Corfu in the south. Its late record was probably explained by misidentification and confusion with robust individuals of Scleropoa rigida (Trinajstić 1997), although a well conducted study of psammophytic vegetation of Rab island from the 1930s (Horvat 1939) explicitly rejected the presence of the mentioned species, despite the fact that it could be expected in that type of vegetation. In the case of Montenegro, it is important to note that the species has not been found in Albanian coastal dunes, which are a natural prolongation of Velika plaža (Fanelli et al. 2015). It is thus possible that the species has colonized Velika plaža recently, as a result of touristic impact. On the other hand, scattered localities may be the result of quite old introduction, or even natural occurrence, which cannot be completely excluded, especially since the whole lowland Montenegro has been much less explored than the mountainous inland. 


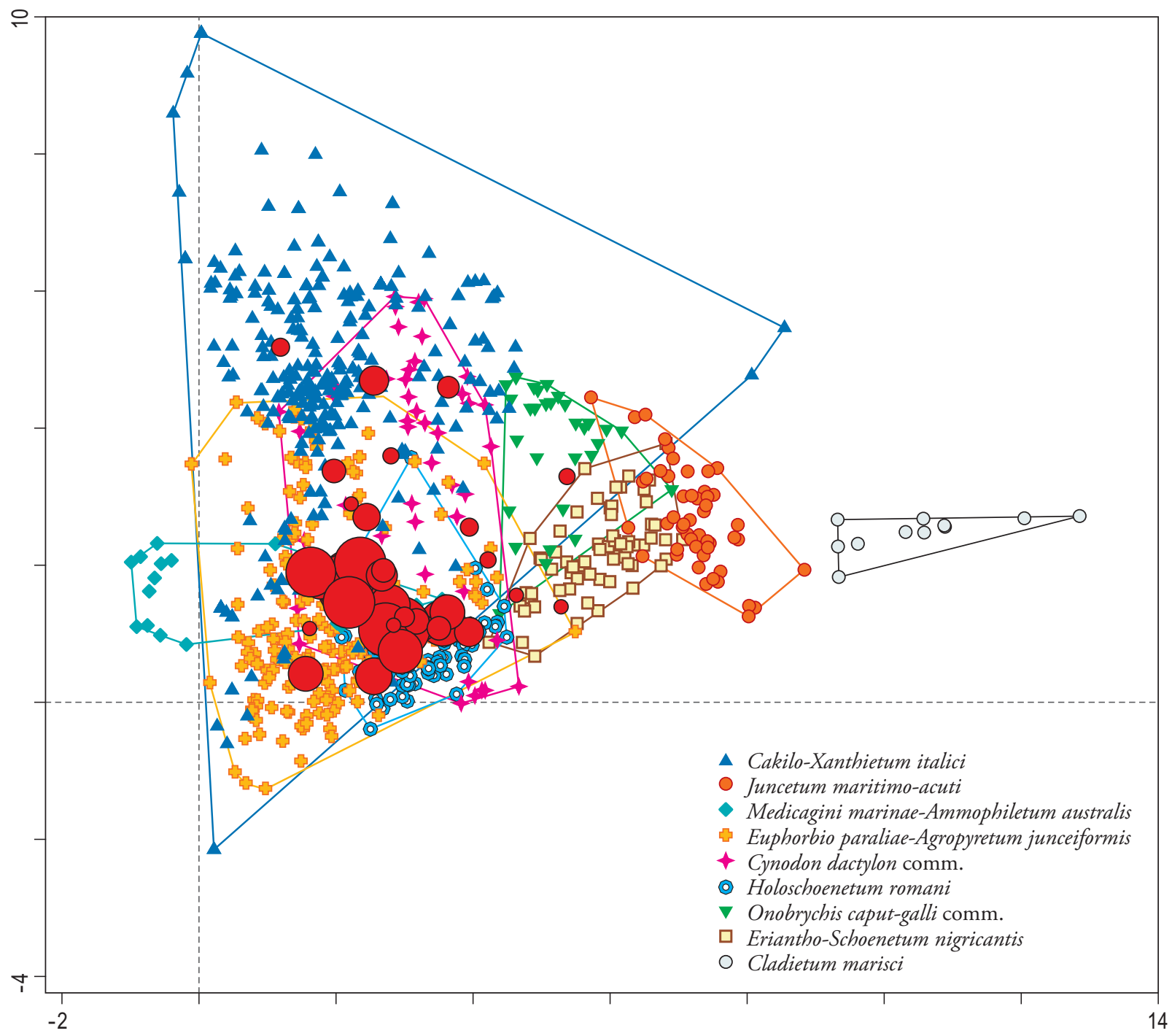

Figure 1: Detrended Correspondence Analysis (DCA) ordination of relevés from 20 transects classified into 9 plant communities (clusters). Size of red circles indicates cover value of Cutandia maritima.

Slika 1: DCA ordinacija popisov iz 20 transektov klasificiranih v 9 rastlinkih združb (klastrov). Velikost rdečih krogov nakazuje pokrovnost vrste Cutandia maritima.

C. maritima is known to be capable of tolerating exposure to intense sea winds and continual movement of sand grains of embryonic dunes facing seawards (Minissale \& Sciandrello 2015). This explains its high frequency within the habitat types: annual vegetation of drift lines (Cakilo-Xanthietum italici (Beg. 1941) Pign. 1953) and embryonic dunes (Echinophoro spinosae-Elymetum farcti Géhu 1988) (Figure 1). It can thus be considered to be one the first pioneer species or colonizer of dunes.

Although the species was recorded in only 4 transects located in the western part of the beach, it is sparsely distributed over almost the entire beach. It should be noted that the $2 \mathrm{~m}$ wide transects were set systematically at a distance of $500 \mathrm{~m}$, so some occurrences may have been overlooked. Furthermore, the cover of $C$. martitima never exceeded the value 1 .

As shown in Table 1, C. maritima frequently occurs in the studied area in annual grasslands with Vulpia faciculata, Lagurus ovatus and Onobrychis caput-galli. This vegetation type has not been studied in detail on Velika plaža in Ulcinj. To date, only plant communities of Cakiletea and Ammophiletea have been reported for the dune area. C. maritima vegetation with the mentioned species can certainly not be classified into Ammophilletea. In the researched transects and numerical classification, we could not separate communities of Malcolmietalia 
and Crucinelletalia orders. More detailed investigations are needed to complete knowledge about the synecology of this species, as well as sabulicolous therophytic plant communities on Velika plaža in Ulcinj.

\section{Conclusion}

In previous studies of the sand dune vegetation of Velika plaža in Ulcinj, only communities of Cakiletea maritimae and Ammophiletea have so far been recognized, while sabulicolous therophytic communities have certainly not been taken into account. After the record of $C$. maritima on Velika plaža in Ulcinj, and some ecological and synecological notes on the species, communities of Cutandietalia maritimi might obviously also be present in Montenegro. However, more detailed phytocoenological research is needed.

\section{Acknowledgements}

The research was partly financed through the Rufford project 14048-1 and research core funding P1-0236 (Slovenian Research Agency).

\section{References}

Bartolo, G., Brullo, S., Minissale, P. \& Spampinato, G. 1988: Flora e vegetazione dell'Isola di Lampedusa. Bollettino dell'Accademia gioenia di scienze naturali 21(334): 119-255.

Bolòs, O. 1996: La vegetació de les Illes Balears. Comunitats de plantes. IEC, Arx. Secc. Ciències, CXIV. Barcelona.

Braun-Blanquet, J. 1964: Pflanzensoziologie. Grundzüge der Vegetationskunde. Springer Verlag, Wien, 865 pp.

Brullo, S. \& Furnari F. 1970: Vegetazione psammofila presso il capo Isola delle Correnti. Pubblicazioni dell'Istituto di Botanica della Universit’ a di Catania, pp. 1-11.

Brullo, S., Di Martino, A. \& Marceno, C. 1974: Osservazioni sulla vegetazione psammofila tra Capo Granitola e. Selinunte (Sicilia occidentale). Bolletino di Studi ed Informazioni del Giardino Coloniale di Palermo 26: 103-110.

Chytrý, M., Tichý, L., Holt, J. \& Botta-Dukat, Z. 2002: Determination of diagnostic species with statistical fidelity measures. Journal of Vegetation Science 13: 79-90.

Costa, J. C., Lousa, M., Espirito Santo, M. D., Sevillano, J. I. \& Arsénico, P. 2000: The coastal vegetation of the Portuguese Divisory Sector: Dune cliffs and low-scrub communities. Finisterra 35: 69-93.

Díez-Garretas, B., Alfredo, A. \& Gavilán, R. 2003: Sabulicolous therophytic plant communities in the Mediterranean Region: a proposal of phytosociological synthesis. Phytocoenologia 33 (2-3): 495-526.
Doing, H. 1985: Coastal Fore-Dune Zonation and Succession in Various Parts of the World. Vegetatio 61 (1-3): 65-75.

Fanelli, G., De Sanctis, M., Gjeta, E., Mullaj, A. \& Attore, F. 2015: The vegetation of the Buna river protected landscape (Albania). Hacquetia 14 (2): 129-174.

Géhu, J.M. \& Géhu-Franck J., 1986: Données synsystématiques et Synchorologiques sur la vegetation du littoral tunisien de Bizerte à Gabès.I. La vegetation psammophile. Documents Phytosociologique 10 (2): $127-155$.

Géhu, J.-M., Costa, M., Biondi, E., Géhu-Franck, J. \& Arnold, N. 1987: Données sur la végétation littorale de la Créte (Grèce). Ecologia Medititerranea 13 (1-2): 93-105.

Géhu, J.M. \& Biondi, E. 1994: La végétation du littoral de la Corse. Essai de synthése phytosociologique. Braun-Blanquetia 13: 3-149.

Glasnović, P. 2009: Report of the working group for plants. In: Presetnik, P. Ecosystems of Adriatic. Society of Biology students, pp. 5-17.

Hennekens, S. M. \& Schaminée, J. H. J. 2001: TURBOVEG, a comprehensive data base management system for vegetation data. Journal of Vegetation Science 12 (4): 589-591.

Horvatić, S. 1939: Pregled vegetacije otoka Raba sa gledišta biljne sociologije. Prirodoslovna istraživanja Kraljevine Jugoslavije 22: 1-96.

JPMD 2015: Completed the second phase on the protection and rehabilitation of sand dunes in the area of Velika plaža in Ulcinj. available online: http://www.morskodobro.com/index. php?limitstart=32\&lang=sr/ access date: October $7^{\text {th }} 2015$.

Kent, M., 2012: Vegetation Description and Data Analysis: A Practical Approach Chichester: Wiley-Blackwell, Oxford, 414pp.

McCune, B. \& Grace, J. B., 2002: Analysis of ecological communities. Glenden Beach: MjM Software Design, Oregon, 300pp.

Mijović A. 1994: Kserohalofitne psamofitske zajednice Velike Ulcinjske plaže. Glasnik Instituta za botaniku i Botaničke bašte Univerziteta u Beogradu 28: 147-157.

Mijović, A., Popović, Z., Karadžić, B., Mijatović, M., Perišić, S., 2006: Distribution of xerohalophytic vegetation along the seaward and landward zone in south-Adriatic sandy beach (Montenegro). Biotechnology and Biotechnological Equipment 20(1): 30-35.

Mijović, A., Popović, Z., Vukov, T., Matić, R., Bojović, S., 2012: Sand topography influences the distribution of xerohalophytic vegetation on a southern Adriatic beach in Montenegro. Plant Biosystems 146(3): 664-673.

Minissale, P. \& Sciandrello, S. 2015: The sabulicolous therophytic associations in Sicily: new insights through the statistical approach, stressing the the continuum versus discrete model of plant communities. Acta Botanica Gallica (162) 1: 55-78.

Official Gazette of Social Republic of Montenegro, SRCG 30/68

Perdigó, M. T. \& Papió, C 1985: La vegetación litoral de Torredembarra (Tarragona). Collect. Bot. 16 (1): 215-226.

Petrović, D. \& Karaman, M. 2009: Important plant areas in Montenegro - IPA Programme. NVO Zelena Gora, Podgorica, 79 pp.

Petrović, D., Hadžiablahović, S., Vuksanović, S., Mačić, V. \& Lakušić, D. 2012. Katalog tipova staništa Crne Gore značajnih za Evropsku uniju. Podgorica-Beograd-Zagreb: 116 pp. 
Pignatti, S. 1982: Flora d'Italia III . Edagricole, Bologna, p. 517.

Rivas Goday, S., Rivas-Martínez, S. 1958: Acerca de la Ammophiletea del Este y Sur de España. An. Inst. Bot. A.J. Cavanilles. 16: 549-564.

Rivas-Martínez, S., Tomás E. Díaz, T.E., Fernández-González, F., Izco, J., Liodi, J. \& Lousa, M. 2002: Vascular plant communities of Spain and Portugal. Addenda to the syntaxonomical checklist of 2001. Itinera Geobotanica 15: 5-922.

Stanisci, A., Acosta, A.T.R., Carranza, M.L., de Chiro, M., Del Vecchio, S., Di Martino, L., Frattaroli, A.R., Fusco, S., Izzi, C.F., Pirone, G. \& Prisco, I. 2014: EU habitats monitoring along the coastal dunes of the LTER sites of Abruzzo and Molise (Italy). Plant Sociology 51 (1): 51-56.

Sykora, K.V., Wageningen, D.B., Babalonas, D. \& Papastergiadou, E.S. 2003: Strandline and sand-dune vegetation of coasts of Greeceand of some other Aegean countries. Phytocenologia 33 (2-3): 409-446.

Šilc, U., Mullaj, A., Alegro, A., Dajić Stevanović, Z., Petrović, M. \& Stešević, D. 2015: Psammophytic vegetation along the eastern Adriatic coast. Phytocoenologia 46 (4): 339-355.

Šilc, U., Caković, D., Küzmič, F. \& Stešević D. 2017: Trampling impact on vegetation of embryonic and stabilised sand dunes in Montenegro. Journal of Coastal Conservation, 21(1): 15-21. van der Maarel, E. \& van der Maarel-Versluys, M. 1996: Distribution and conservation status of littoral vascular plant species along the European coasts. Journal of Coastal Conservation 2: 73-92.

Ter Braak, C.J.F. \& Šmilauer, P. 2012: Canoco reference manual and user's guide: software for ordination, version 5.0. Microcomputer Power, Ithaca, USA, $496 \mathrm{pp}$.

Tichý, L. 2002: JUICE, software for vegetation classification. Journal of Vegetation Science 13: 451-453.

Trinajstić, I. 1989: Prilog poznavanju vegetacije priobalnih pješčanih sprudova razreda Ammophiletea Br.-Bl. \& Tüxen 1943 u Crnogorskom primorju. CANU Glasn. Odjelj. Prir. Nauka (Titograd). 7: 45-51.

Trinajstić, I. 1997: Cutandia maritima (L.) Benth. (Poaceae) a new species of the Croatian flora (In Croatian with English summary). Acta Botanica Croatica 55/56: 133-137.

Tutin, T.G., Heywood, V.H., Burges, N.A., Moore, D.M., Valentine, D.H., Walters, S.M. \& Webb, D.A. 1964/80: Flora Europeaea, Vol 1-5. Cambridge University Press, Cambridge, pp. 370, 452, 455, 464 $\& 505$.

Zimmitti, A., Mangiafico, R. \& Pitruzzello, P. 2015: Requalification of coastal plant landscape of South-Eastern Sicily, Italy: the case of Marina di Priolo. Biodiversity Journal 6 (1): 165-170. 
Table 1: Cutandia maritima in the vegetation of Velika plaža (Montenegro).

Tabela 1: Vrsta Cutandia maritima v rastlinskih združbah na Veliki plaži (Črna Gora).

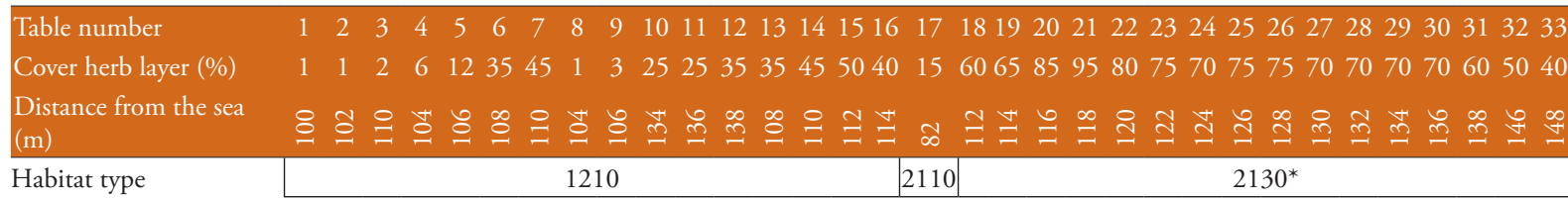

Cutandia maritima

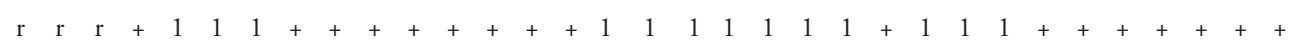

Cakiletea maritimae

Xanthium italicum

Salsola kali

\section{Ammophiletea}

Cyperus capitatus

Echinophora spinosa

Euphorbia terracina

Alkanna tinctoria

Medicago marina

Pancratium maritimum

Eryngium maritimum

Elymus farctus

Scolymus hispanicus

Lagurus ovatus

Pseudorlaya pumila

\section{Sedo-Scleranthetea}

Hypochaeris radicata

Arenaria serpyllifolia agg.

Tunica saxifraga

Trifolium campestre

\section{Helianthemetea guttati}

Vulpia fasciculata

Catapodium rigidum

Artemisietea vulgaris

Bromus diandrus

Verbascum sinuatum

Dasypyrum villosum

\section{Juncetea maritimi}

Imperata cylindrica

Holoschoenus romanus

Parapholis incurva

\section{Others}

Medicago littoralis

Onobrychis caput-galli

Crepis foetida

Cerastium sp.

Chondrilla juncea

Cynodon dactylon

Conyza albida

Phleum arenarium

Oenothera spp.

Pinus sp. 